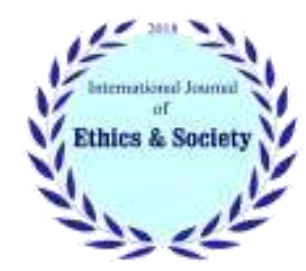

International Journal of Ethics \& Society (IJES)

Journal homepage: www.ijethics.com

Vol. 2, No. 3 (2020)

(Original article)

\title{
Ethical Leadership Style \& the Dark Personality Dimensions of Effective Person in Earnings Management
}

\author{
Mostafa Zangiabadi ${ }^{\mathrm{a}}$, Farzaneh Nassirzadeh ${ }^{\mathrm{b}}$ \\ a) PhD Student, Dept. of Accounting, Faculty of Economics \& Business Administration, Ferdowsi University of \\ Mashhad, Mashhad, Iran. \\ b) Dept. of Accounting, Faculty of Economics \& Business Administration, Ferdowsi University of Mashhad, \\ Mashbad, Iran
}

\section{Abstract}

Background: Management personality is one of the critical factors influencing their behavior in performing earnings management (EM). As a result, the dark (negative) personality dimensions can play an effective role in earnings management. On the other hand, ethical leadership can act as a moderating factor; this research measures the effect of ethical leadership style on reducing dark personality dimensions (Machiavellianism, psychopathy, narcissism) of effective person in earnings management.

Method: The present applied research uses descriptive-survey method and the correlation approach. The statistical population of this study is companies listed in the Tehran Stock Exchange (TSE) and Iran Fara Bourse (IFB) from 2011 to 2019 and based on some limitations 77 companies used in this research for testing the hypotheses. And standard questionnaires of dark personality and ethical leadership and financial statement data have been used. Also, the multiple regression test and structural equations model used. the data were analyzed using R 3.1.2 and Lisrel 8.8 software.

Results: The results show that most of the effective persons in earnings management are the CEOs of companies. The results also indicate a positive relationship between ethical leadership and dark personality dimensions (Machiavellianism, psychopathy, narcissism).

Conclusion: The results indicate a positive relationship between ethical leadership and the dimensions of the dark personality; This is due to the closeness of dimension of "Narcissism" to the issues of intrinsic leadership, and on the other hand, this issue could be considered close to the perspective of the person involved in earnings management and supervisors and lack of belief in ethical supervision and leadership.

Keywords: Dark Personality, Ethical Leadership, Earnings Management.

* Corresponding Author: Email: nasirzadeh@um.ac.ir

Received: 14 Dec 2020

Accepted: 30 Dec 2020 


\section{Introduction}

One of the purposes of financial statements is to help assess the performance of management in using resources that is used to inform shareholders of the effective use of resources. Earnings is one of the most basic elements of financial statements always considered by users stated as a criterion for evaluating the continuity of activity, efficiency and reviewing the structure of contracts of representatives of economic units. Indeed, earnings are a tool to overcome the problems of measuring and evaluating the performance of institutions (1). One of the factors that can affect the future profitability of companies is EM as the process of selecting accounting procedures by management to reach specific goals that can affect future profitability and thus reach goals like meeting analysts' forecasts, increasing shareholder wealth and management rewards (2). According to Agency Theory, managers manage earnings in line with their interests and fraudulently contrary to accepted accounting principles to meet the expectations of financial analysts (3). On the other hand, the increase in the company's recent scandals shows the spread of abuse, fraud and distortion of financial reporting and earnings management (4). Earnings management has been introduced as one of the problems of the accounting profession that not showing the real financial state of the organization and hides relevant information the investors should know. This management behavior can cause ethical failure in companies (5).

Some accountants consider EM as a common and correct practice (6) and others as an unacceptable one, yet it is agreed that managers face considerable pressure from conflict of interest to manage earnings. This pressure causes some of them overexposed to unethical behavior (7). One of the elements effective in this unethical and dysfunctional behavior is the personality of the individual, some scholars $(8,9)$ have stated that the people with dark personality traits are more likely to be involved in unconventional or unethical behaviors compared to the general public; thus, EM can originate from the dark personality of the manager.

Dark personality (Dark Triad) was suggested by Paulhus and Williams (2002). Dark personality traits comprise three corelated subsets of individuals' personalities, including narcissism, Machiavellianism, and psychopathy. These dimensions are recognized as deviated or abnormal personality structures (10).

The last two decades have seen growing interest in the role of the Dark Triad traits (i.e., narcissism, psychopathy and Machiavellianism;11) in occupational settings (12). The increasing interest in the Dark Triad personality traits has examined its association with negative vocational outcomes, such as workplace deviance and counterproductive behaviors $(9,10)$. However, despite these undesirable outcomes, some evidence indicates that individuals with Dark Triad characteristics are nonetheless still commonly recruited and given strategic roles in the workplace (9).

Persons with narcissism, Machiavellianism, and psychopathy desire self-superiority and deviating behaviors. Narcissism includes features such as pride, deliberate superiority, and drawing attention (11). Narcissism is construed as behaviors such as distress and disagreement (13). Machiavellianism is defined as using opportunistic and demagogic behaviors in order to weaken others (14).

Some scholars $(15,16)$ did different studies about personality, and they suggested that people with dark personalities exploit their subordinates and repress their people around. These persons may damage their associates, and their pretense to honesty and self-confidence produce short-term successes. Hence, such negative personality features lead to negative organizational and individual behaviors. Another researchers showed that people with dark personality features like to be poorly perceived socially $(11,17)$, to apply penetrative-offensive features (18), and to do inefficient behaviors (8). These inefficient behaviors include actions to damage 
Company, sabotage, theft, and fraud from staff (19).

The above researches have suggested a positive relation between dark personality features (narcissism, Machiavellianism, and psychopathy) and inefficient and unethical behaviors. However, the some researches $(10,20)$ confirm that personality is not the mere effective feature that promotes or weakens this relation. However, there are other variables, such as ethical leadership style. the Some scholars (11) showed that people with dark personality features have several behavioral patterns. Narcissists believe themselves more predominant than others, and Machiavellians believe that they can deviate from their tricks and skills to acquire predominancy.

Furthermore, people with high psychopathy intend to follow their goals at any cost. Consequently, upon the mutual relations of these dimensions, such people believe that the best way is exploiting others and ignoring the law to preserve their goals. Such features accompany a low level of ethical leadership (21). Based on social exchange theory, managers may use a cost-benefit analysis and the expectation of reciprocity from their leader to choose their subsequent behaviors. This means managers may refrain from engaging in unethical and opportunistic behaviors if they feel their leader treats them fairly and acts in a just manner (22). Workplace spirituality (e.g., ethical leadership) moderated the association of Machiavellianism, psychopathy, and narcissism with instigated incivility to supervisors and colleagues (23). So, ethical leadership had an effective role in reducing dark triad personality traits of people involved in earnings management (unethical and opportunistic behavior).

Ethical leadership is one of the dimensions of ethics and leadership $(24,25)$. Ethical leadership manifests proper normal behaviors through individual and interpersonal actions and expedites those behaviors through mutual communications, force, and decision-making. Ethical leadership occurs when a leader behaves his staff fairly and honestly, and provides a responsiveness culture in an organization (24), and causes diminishing inefficient and unethical behaviors $(15,26)$. In other words, if staff feel their leaders behave fairly and honestly, they avoid inefficient behaviors (22). Moreover, if staff see a conflict between the behaviors and standards that the leader tries to apply them, they ignore his speeches (24).

In ethical leadership, abnormal and inefficient behavior is one of the most crucial output variables. Many researchers also showed that ethical leadership cause decrement of inefficient behaviors of staff (16) through facilitating situation and produces a bad ethical atmosphere in the organization (27) and affects the relationship between personality and unethical behaviors $(10,20)$. Since earnings management is one of the unethical behaviors in the accounting field (7) which initiates from people's personalities, and, on the other hand, due to effectiveness of ethical leadership style in promoting or weakening of relationships between personality and unethical behaviors, it is expected that ethical leadership style affects the reduction of dark dimensions (triad) of people involved in earnings management.

An array of CEO characteristics has been examined in the literature in Iran (e.g., 26,27,28) but the dark dimensions of CEO or CFO have not been studied. and in the literature, selection of an effective person in Earnings management was without conducting any test, and the financial manager has been chosen as an effective person in Earnings management (e.g., 27). On the other hand, existing research in the ethical leadership's literature (e.g., $29,30,31,32,33,34)$ has only dealt with the ethical or non-ethical nature of earnings management. And in Iranian personality literature, the effect of ethical leadership style on reducing the dark dimensions of personality has not been studied. Therefore, this article seeks to integrate and extend limited existing findings regarding the impact of ethical leadership on reducing dark personality dimensions of effective people in earnings management as unethical behavior in the accounting literature.

The rest of the present study is organized as follows: the next part frames the study into a theoretical framework, hypotheses development, and literature. Section 3 describes the Research methodology and outlines where data is obtained and the sample selection procedure. The next one then talks about the main results and implications drawn 
from statistical analyses. Finally, the last sections present the Discussion and Conclusion.

\section{Theoretical framework and hypothesis devel- opment}

2.1Dark personality dimensions and earnings management The relation between Dark personality dimensions and earnings management is introduced by the Upper Echelon Theory. This theory argues that managers' personalities, values, and experiences have substantial effects on performance, selection, and management decisions (35). Thus, this theory can be considered as a fundamental one in this research. Accordingly, Some scholars $(36,37,38)$ suggested a relation between personality features of Machiavellianism and earnings management. In other words, since people with higher Machiavellian features are persons with problematic and most risky behaviors and support for extremism, they desire to deviate financial reports and accounting data by earnings management. Researcher (39) also showed this matter by proving the relation between dark personality and opportunistic behaviors. They phrased that deviated features of people with dark personalities directed them toward opportunistic behaviors.

In a company, people with dark personality features continuously suppose leadership and managerial situations and seek those businesses that can manipulate their results and control other people (40). They try to control their followers by political motives, and they try to affect others by their managerial methods and their inherent talents. Such people do not care about ethical procedures and standards and mostly concentrate on their potentials $(38,40)$, and they continuously follow managing operation results $(29,36)$, misleading financial reports (41), changing budgeting and authoritative management (42), and opportunistic (39). This always represents their actions negatively. They feel predominance due to their fake self-confidence, while their results may be worse than those of other people (43). However, despite these undesirable outcomes, some evidence indicates that individuals with Dark Triad characteristics are nonetheless still commonly recruited and given strategic roles in the workplace
$(9,44,45)$. Unfortunately, limited studies have examined the Dark Triad traits' impact on positive occupational outcomes $(9,12,45)$.

\subsection{Dark personality dimensions and ethical leadership}

People with Dark personality features look at others negatively. Researches mention such phenomenon as pessimistic desires. People with dark personalities consider others angry, depressed, anxious, and with low self-confidence (46). Machiavellian people consider others less social, dull, and less skillful (17). They conceive others as pessimistic and unethical. They assume others shall merely serve them and exploit others to achieve their goals (14). These people perceive accounting manipulations as acceptable because they usually make unethical decisions. Due to their authoritative and managerial desires, they try to achieve their goals by deviating information and overcoming their subordinates (36). They attach little importance to their companies and social responsibilities, and they do not avoid unethical behaviors, such as tax escape (47). These persons assume other unsophisticated persons with closed minds, individualist, and unskillful.

Consequently, they have little ethical leadership perceptions. Assuming others as unsophisticated persons in Machiavellianism means such people do not account for their subordinates' ethical growth (as a part of ethical leadership criteria). So, such people construe others as beginners and under-social persons, which may negatively affect Machiavellianism and ethical leadership criteria (21). Therefore, Machiavellians assume their leaders as unethical persons. On the other hand, in applying ethical leadership by top managers in a company, down managers reduce their Machiavellian behaviors regarding unethical earnings management. Thus, we can suggest the following hypothesis: H1: Applying ethical leadership by top managers reduces the Machiavellian behaviors of people involved in earnings management.

Narcissists are low-conscience and negative-oriented persons (8). They assume others as conscienceless, disagreeable, and unethical persons $(17,46)$. People with dark personality features do 
not construe their leaders as ethical-oriented persons systematically. People with dark personality features have behavioral patterns accompanied by low ethical leadership levels. Narcissists have predominant views, and they believe that they can outfox others to obtain domination. Consequently, narcissists may extend their views to successful persons (e.g., their leaders). Thus, if one believes in exploiting others and ignoring the law in the best way, he feels this is the way of successful persons, such as ethical leaders, so he applies similar procedures for achieving his goals (21). But some studies (48) provide consistent evidence that narcissism is a significant positive factor in both leadership role occupancy and hiring decision in a collectivist culture. Since narcissists are negative-oriented persons, so they do not assume their leaders as ethical persons. Hence, they do not have ethical perceptions of their leaders. On the other hand, applying ethical behaviors by top managers of a company reduces down managers' narcissism involved in earnings management. So, we expect:

H2: Applying ethical leadership by top managers reduces the Narcissistic behaviors of people involved in earnings management.

Psychotic persons believe others are undependable, so they assume others untrustworthy (26), have no penitential senses, and they want to achieve their goals at any cost (11). Existence of such a feature in people disorders social relations and flexibility. Psychopathy is accompanied by lack of penitence, lack of logical thinking, untrustworthy, duplicity, poor judgment, deviating behaviors, weak conscience, and short-term decisions. This feature can be a part of unacceptable criteria for ethical leadership (49). Authors believe that psychotic persons are socially dangerous and without competence (10). The existence of psychotic persons in a company causes an increment of staff's distraction and anxiety, business struggles, and dissatisfaction (50). However, such persons usually do more administrative activities, and they can correlate unrelated concepts due to their high-level creativity (49). Such persons' selfish behaviors may result from an unethical leadership that produces an inefficient leadership style (51). Such persons construe their leaders similar to themselves and as unethical, undependable, and mindless persons (21). Thus, it is expected that psychopathy personality has a negative relation with the perception of ethical leadership. On the other hand, an ethical leader in a company causes a decrement in psychotic behaviors of down managers. Thus, we have:

H3: Applying ethical leadership by top managers reduces the psychopathic behaviors of people involved in earnings management.

\section{Material and Methods}

The method of the present study is descriptive and correlational according to the nature, goals and hypotheses of the research. This research is one of the applied researches in terms of purpose. The statistical population of this study is companies listed in the Tehran Stock Exchange (TSE) and Iran Fara Bourse (IFB) from 2011 to 2019. the following limitations were applied for the selection of companies in the sample of this research:

\section{Table 1: Sample statistical data}

\begin{tabular}{|c|c|c|c|}
\hline Row & & Item & $\begin{array}{l}\text { Quan- } \\
\text { tity }\end{array}$ \\
\hline 1 & & $\begin{array}{l}\text { Total registered companies } \\
\text { ended on Mar. 20, } 2019\end{array}$ & 773 \\
\hline 2 & \multirow{5}{*}{. } & $\begin{array}{l}\text { financial intermediation indus- } \\
\text { try, holding companies, and } \\
\text { banks }\end{array}$ & 113 \\
\hline 3 & & $\begin{array}{l}\text { Companies registered in TSE } \\
\text { and IFB after } 2011\end{array}$ & 134 \\
\hline 4 & & Companies with deleted Isin & 15 \\
\hline 5 & & $\begin{array}{l}\text { Companies without available } \\
\text { data during the research period }\end{array}$ & 51 \\
\hline 6 & & $\begin{array}{l}\text { Companies with replaced CEO } \\
\text { during the last two years }\end{array}$ & 383 \\
\hline 7 & & Statistical society & 77 \\
\hline 8 & & Sample companies & 77 \\
\hline
\end{tabular}

Purposeful Sampling Method was used for the selection of the sample. For selecting involved persons in earnings management, a company was selected if its CEO was not replaced (who is available for responding to the questionnaire), but its CFO was replaced, from 2011 to 2019. If earnings management was not changed by replacing the 
manager (CEO), it was concluded that the involved person in earnings management was CFO. If earnings management was changed by replacing the manager, it was concluded that the involved person in earnings management was the CEO. The demographic characteristics of the involved person in earnings management are given in Table 2.

Table 2: Demographic information of research

\begin{tabular}{|c|c|c|}
\hline Type & Groups & Percent \\
\hline \multirow{2}{*}{ Gender } & Female & 14 \\
\hline & male & 86 \\
\hline \multirow{3}{*}{ Education } & Under B.A & 0 \\
\hline & B.A & 32 \\
\hline & M.A and upper & 68 \\
\hline \multirow{3}{*}{ Years of service } & 1 to $10 \mathrm{ys}$ & 20 \\
\hline & 11 to $20 \mathrm{ys}$ & 36 \\
\hline & Up to $21 y s$ & 44 \\
\hline
\end{tabular}

After distinguishing the involved persons in earnings management, Personality's Standard Questionnaire (11) is used to measure the dark personality dimensions of a person (dependent variable). And is graded on a 5-point Likert scale. While confirming the validity of the questionnaire by the professors, the reliability of the instrument by Cronbach's alpha method in the present study was 0.718. Ethical Leadership's Standard Questionnaire (24) is used to measure adjusting effects of ethical leadership style (independent variable). And is graded on a 5-point Likert scale. While confirming the validity of the questionnaire by the professors, the reliability of the instrument by Cronbach's alpha method in the present study was 0.944. This questionnaire is distributed between several staff who are aware of the decisions of the Board of Directors to measure the leadership style of top managers of persons involved in earnings management.

Also, we shall measure accrual earnings management for the determination of the involved person in earnings management. So, Kasznik's (1999) model and Jones's (1995) adjusted model were used; the model with better fitness results (according to goodness fit criteria) will be selected as the final model for accrual earnings management, and the absolute value of the remainder of this model will be considered as a criterion for accrual earnings management:

$T A C C_{i t} / T A_{i t-1}=\alpha\left(1 / T A_{i t-1}\right)+\beta_{1}\left(\triangle R E V_{i t}-\triangle R E C_{i t}\right) /$

$T A_{i t-1}+\beta_{2}\left(P P E_{i t} / T A_{i t-1}\right)+\beta_{3}\left(\triangle C F O_{i t} / T A_{i t-1}\right)+\varepsilon_{i t}(1)$

This model assumes that changes of unmanaged accruals due to the Company's economic transactions (TACC) obtained by deduction of operational cash flows (CFO) from operational profit $(\mathrm{OP})$ is due to changes of revenue (REV) than the previous period, changes of accounts receivable (REC) to include the effects of credit sales and to neutralize the assumption of revenue exogeny, the gross amount of properties, machinery and equipment (PPE), and operational cash flows (CFO). Each item was divided by total period start properties (TA) to control company size and homogeneity variables (52).

$T A C C_{i t}=\alpha\left(1 / T A_{i t-1}\right)+\beta_{1}\left(\triangle R E V_{i t}-\triangle R E C_{i t}\right) / T A_{i t-1}+$ $\beta_{2}\left(P P E_{i t} / T A_{i t-1}\right)+\varepsilon_{i t}$

This model assumes that changes of unmanaged accruals due to the Company's economic transactions (TACC) is due to changes in revenue (REV) than the previous period, changes of accounts receivable (REC) to include the effects of credit sales and to neutralize the assumption of revenue exogeny, the gross amount of properties, machinery and equipment (PPE). Each item is homogenized by total period start properties (TA) (53).

After identifying the involved person in earnings management, Structural Equations Model and gathered data by questionnaires at the end of 2018 and beginning of 2019 were used. Since standard regression analyses substantially ignore many measurement errors in descriptive variables, and it is not possible to study the direct and indirect effects of involved variables in a pattern, and the relation between dependent variables and independent variables is not clear in these patterns (54), Structural Equations Model is used. we use Lisrel 8.8 Software and Structural Equations Model to determine their relationships.

\section{Results}


To select a model, among the two above, for evaluation of accrual earnings management, the available models were fitted optimally (after controlling classic assumptions), and the results of goodness fit criteria are shown in Table 3.

Table 3: Selection of optimal model

\begin{tabular}{|l|l|l|}
\hline \multicolumn{1}{|c|}{ Criterion } & $\begin{array}{l}\text { Kasznik's } \\
\text { model }\end{array}$ & $\begin{array}{l}\text { Jones's } \\
\text { Model }\end{array}$ \\
\hline R-squared & 0.66 & .73 \\
\hline Adjusted R-squared & 0.65 & .68 \\
\hline F statistic & 52.14 & 13.95 \\
\hline$P$-value & 0.000 & 0.000 \\
\hline $\begin{array}{l}\text { Durbin-Watson sta- } \\
\text { tistic }\end{array}$ & 1.53 & 1.87 \\
\hline $\begin{array}{l}\text { Independent varia- } \\
\text { bles }\end{array}$ & 3 & 2 \\
\hline Significant variables & 2 & 0 \\
\hline
\end{tabular}

Because of having goodness fit criteria, Kasznik's (1999) model is better as the final model for determining accrual earnings management. Next, we shall determine the person involved in earnings management. The optimal fitness of regression for replacing the $\mathrm{CEO}$ on earnings management in the sample indicates a significant relationship between the two above variables in most companies. Table 4 shows some of the results for effective persons on earnings management. According to the given fitness model results, when earnings management changes had no significant relation with the CEO's replacement, changes in earnings management were attributed to CFO.

Table 4: A sample of results for determination of involved person in earnings management

\begin{tabular}{|c|c|c|c|c|}
\hline ISIN & Coefficient & $t$-student & \multicolumn{1}{c|}{$P$-value } & \multicolumn{1}{c|}{ The effective person on earnings management } \\
\hline BHPZ & 0.058187 & 3.055603 & $0.028243^{*}$ & CEO \\
\hline NARP & 0.002309 & 0.023231 & 0.982365 & CFO \\
\hline FIBR & -0.048399 & -1.269916 & 0.260004 & CFO \\
\hline CHAR & -0.056618 & -3.854542 & $0.011946^{*}$ & CEO \\
\hline SDRP & -0.128242 & -4.550982 & $0.006107^{*}$ & CEO \\
\hline NMOH & -0.037762 & -1.299421 & 0.250484 & CFO \\
\hline SDAB & 0.050207 & 3.688295 & $0.014171^{*}$ & CEO \\
\hline NBEH & 0.163657 & 2.628362 & $0.046625^{*}$ & CEO \\
\hline SHLP & -0.096431 & -48.39896 & $7.11 E-08^{*}$ & CEO \\
\hline MINZ & 0.094490 & 10.66235 & $0.000126^{*}$ & CEO \\
\hline FRBZ & 0.123820 & 2.757926 & $0.039933^{*}$ & CEO \\
\hline PKER & 0.165645 & 4.413057 & $0.006937^{*}$ & CEO \\
\hline MRJZ & 0.117945 & 4.110272 & $0.009261^{*}$ & CEO \\
\hline PYAP & -0.058049 & -4.530684 & $0.006222^{*}$ & CEO \\
\hline \multicolumn{7}{c}{ Note(s): $*: 90 \%$ confidence level } \\
\hline
\end{tabular}

After identifying the involved person in earnings management, structural equations model and gathered data by questionnaires at the end of 2018 and the beginning of 2019 were used. After the initial estimation of the Structural Equations Model, the model's fitness was evaluated to determine the results' reliability. Chi-square Index is the most common index for determining the fitness situation of a model (55). The reasonable interpretation of fitness indices requires deciding critical points or truncation points of related amounts in these indices. Some Researchers (56) proposed a significant level greater than $5 \%$ as the desired value in this test for the chi-square value. Besides, we can use other indices mentioned in Table 5 for fitness evaluation. Table 5 shows the general fitness of this model and includes absolute fitness, comparative fitness, and economic fitness. It also shows the value of each index, optimal value, and the related reference.

Regarding the available data, we can conclude that the Chi-square index has a significant level greater than $5 \%$, so the null assumption indicating goodness of fitness is not rejected. Of course, since the ratio of Chi to freedom degree is less than 5 , we can 
conclude that the model has good fitness. Also, since the Root-Mean-Square of Error (RMSE) is less than $7 \%$, the goodness of fitness is confirmed. It should be mentioned that the other given values for other goodness fit indices indicate the excellent fitness of this model. Therefore, the structural equations model can be suitably used for testing and analysis in this model.

Table 5: Results of the goodness of fitness of structural equations model

\begin{tabular}{|c|c|c|c|c|}
\hline $\begin{array}{l}\text { Goodness } \\
\text { fit criteria }\end{array}$ & Index & Symbol & Value in model & $\begin{array}{l}\text { Acceptable value } \\
\text { (Reference) }\end{array}$ \\
\hline \multirow{2}{*}{$\begin{array}{l}\text { Absolute } \\
\text { fitting index }\end{array}$} & $\begin{array}{l}\text { Chi-square } \\
\text { (sig. level) }\end{array}$ & Chi-square & $\begin{array}{l}18.05 \\
(p>0.05)\end{array}$ & $\begin{array}{l}\text { sig }>5 \% \\
(56)\end{array}$ \\
\hline & Goodness fit index & GFI & 0.97 & $\begin{array}{l}\text { result }>95 \% \\
(56)\end{array}$ \\
\hline \multirow{2}{*}{$\begin{array}{l}\text { Comparative } \\
\text { fitting index }\end{array}$} & Comparative fit index & CFI & 0.92 & $\begin{array}{l}\text { result }>95 \% \\
(56)\end{array}$ \\
\hline & Incremental fit index & IFI & 0.92 & $\begin{array}{l}\text { result }>95 \% \\
(56)\end{array}$ \\
\hline \multirow{2}{*}{$\begin{array}{l}\text { Parsimony } \\
\text { fitting index }\end{array}$} & Root-square mean error approximation & RSMEA & 0.012 & $\begin{array}{l}\text { result }<7 \% \\
(57)\end{array}$ \\
\hline & Chi-square / freedom degree & Chi-squar / df & 4.5 & $\begin{array}{l}\text { result }<5 \% \\
(58)\end{array}$ \\
\hline
\end{tabular}

After ensuring the reliability of the given fitness model results, the path coefficients and $t$-student values are shown in Table 6 and Graph 1. Also, we see the relation between the dark personality variable as an unobserved variable and dark personality dimensions in Table 6. This is also true for the relation between dark personality dimensions and ethical leadership. As you see, there is a positive relation (0.82) between dark personality dimensions and ethical leadership, which indicates the inefficiency of ethical leadership style in the decrement of dark personality dimensions of involved persons in earnings management. And, it could be considered as the closeness of the perspective of the person involved in earnings management and its supervisors and lack of belief in ethical supervision and leadership.
Table 6: Results of structural equations approach

\begin{tabular}{|c|c|c|}
\hline Route & Coefficient & $t$-student \\
\hline $\begin{array}{l}\text { Machiavellianism } \longrightarrow \\
\text { Dark personality }\end{array}$ & 0.72 & $7.31^{*}$ \\
\hline $\begin{array}{l}\text { Narcissism } \longrightarrow \\
\text { Dark personality }\end{array}$ & 1.03 & $10.15^{*}$ \\
\hline $\begin{array}{l}\text { Psychopathy } \longrightarrow \\
\text { Dark personality }\end{array}$ & 0.51 & $5.12^{*}$ \\
\hline $\begin{array}{l}\text { Ethical leadership } \longrightarrow \\
\text { Dark personality }\end{array}$ & 0.82 & $11.48^{*}$ \\
\hline
\end{tabular}

Graph 1. Shows the Conceptual model with path coefficients and $t$-student values. The results of Table 6 are the same as the results of Graph 1 and the interpretation of the results is presented at the top of Table 6.

\section{Graph 1: Conceptual model of research}

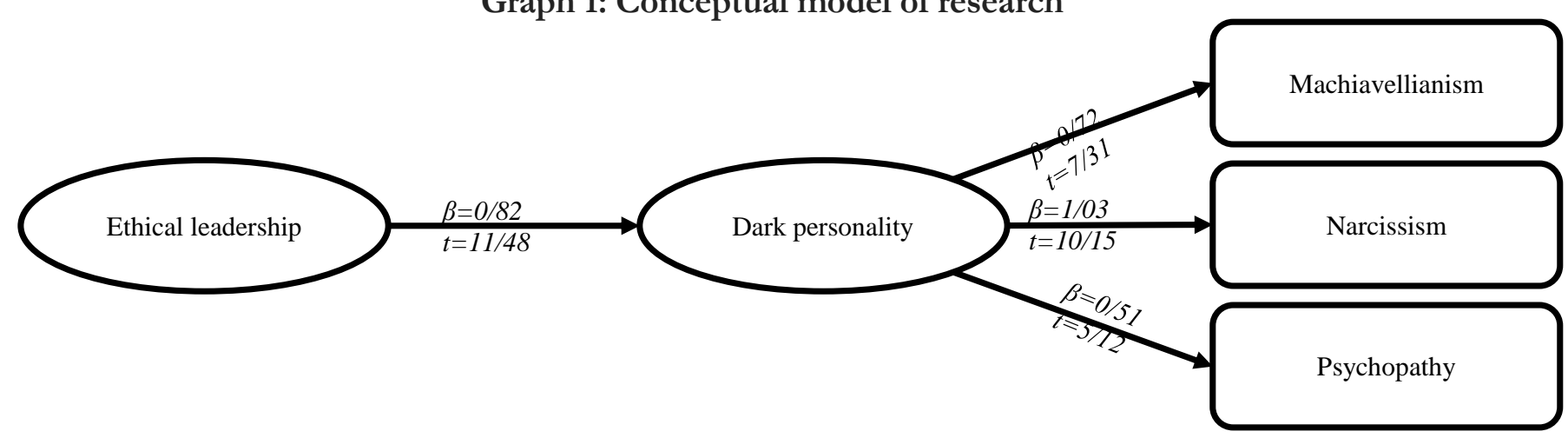

54

Available at: www.ijethics.com 
Table 7 Shows a Summary results about the confirmation of research hypotheses. The values for the relation factor were extracted from Table 6 . The notable point in Table 7 is the positive relation between dark personality dimensions and ethical leadership. This is due to the closeness of the dimension of "Narcissism" to the issues of intrinsic leadership, and on the other hand, this issue can be considered close to the perspective of the person involved in earnings management and supervisors and lack of belief in ethical supervision and leadership.

Table 7: Results of research hypotheses

\begin{tabular}{|l|l|l|l|}
\hline Hypothesis & Coefficient & \multicolumn{1}{c|}{$\begin{array}{l}\text { Resulted } \\
\text { relation }\end{array}$} & Result \\
\hline $\begin{array}{l}\text { The negative relation } \\
\text { between ethical leader- } \\
\text { ship and Machiavellian- } \\
\text { ism }\end{array}$ & $0.82 \times 0.72$ & Positive & \\
\hline $\begin{array}{l}\text { The negative relation } \\
\text { between ethical leader- } \\
\text { ship and Narcissism }\end{array}$ & $0.82 \times 1.03$ & Positive & \\
\hline $\begin{array}{l}\text { The negative relation } \\
\text { between ethical leader- } \\
\text { ship and psychopathy }\end{array}$ & $0.82 \times 0.51$ & Positive & \\
\hline
\end{tabular}

\section{Discussion}

accounting profit is one of the items of financial statements that has been noticed by many beneficiaries and users of financial statements because this item includes essential information for other beneficiaries and managers as rewards. Therefore, many managers and providers of such financial statements and reports try to adjust their profit values to preserve their own companies' benefits and their benefits (1).

An earnings management still exists because having a positive impact for a company. For instance, in view of earnings management from the perspective of efficient contracting, it gives managers an earnings management flexibility to protect themselves and the company in anticipation of events unexpected to join the parties involved in the contract. The manager has the flexibility to choose among several alternative ways of recording transaction as well as selecting the options that exist within the same accounting treatment (59).

However, earnings management also gives a bad effect to the company, managers see it as opportunistic behavior to maximize their bonuses. Consequently, some groups of society have different perceptions, whether earnings management is ethical or unethical (60).

According to the Upper echelon, several factors affect the decisions of managers and providers of financial statement for adjusting the earnings. One of the effective factors is personality, values, criteria, and experiences of management (35). So, some scholars (e.g., 8,9) have stated that the people with dark personality traits are more likely to be involved in unconventional or unethical behaviors compared to the general public; thus, EM can originate from the dark personality of the manager. Dark personality traits comprise three corelated subsets of individuals' personalities, including narcissism, Machiavellianism, and psychopathy. These dimensions are recognized as deviated or abnormal personality structures (10). On the other hand, based on social exchange theory, managers may use a cost-benefit analysis and the expectation of reciprocity from their leader to choose their subsequent behaviors. This means managers may refrain from engaging in unethical and opportunistic behaviors if they feel their leader treats them fairly and acts in a just manner (22). So, ethical leadership had an effective role in reducing dark triad personality traits of people involved in earnings management (unethical and opportunistic behavior).

So, because Less research has examined the Dark Triad traits and ethical leadership in Iran. This article seeks to integrate and extend limited existing findings regarding the impact of ethical leadership on Dark Triad traits of people involved in earnings management in the listed companies in TSE and IFB. The results of this research indicate that the most involved people in earnings management were CEOs of companies. Also, the results indicate that there is a positive relationship between 
ethical leadership and dark personality dimensions. On the other hand, this is due to the closeness of the "Narcissism" dimension to intrinsic leadership issues. The results of the present research contradicts previous research mentioned in the "Theoretical framework and hypothesis development" section (e.g., 7,19,23-25,34,21). It could be considered the closeness of the person's perspective involved in earnings management, its supervisors, and lack of belief in ethical supervision and leadership in Iran. And less research has examined the association between Dark Triad personality traits with positive vocational outcomes.

\section{Conclusion}

Several factors affect the decisions of managers and providers of financial statements for adjusting the earnings. One of the effective factors is personality. On the other hand, management's personality and situation are effective in goal-setting, decision-making, and activities of the Company. In other words, management situation is one of the effective factors in providing financial information; so that if a manager works in an environment with an ethical-oriented leadership style, he probably will not be successful in opportunistic management, and the existence of an ethical leadership style in an organization cause decrement of unethical behaviors in earnings management.

Therefore, regarding the cases mentioned earlier, this research examines the effects of ethical leadership style on dark personality dimensions of people involved in earnings management in listed companies in TSE and IFB. The results of this research indicate that the most involved people in earnings management were CEOs of companies. Also, the results indicate that there is a positive relationship between ethical leadership and dark personality dimensions. This result shows that in the sample of this research, the ethical leadership style of the company is not effective or there is no belief in the ethical leadership style in the company. On the other hand, this result may be due to the lack of identification of other factors affecting the dark dimensions of the personality, which, if the effects of these factors are controlled, it is possible to obtain different results. Finally, according to the findings of this research suggested to authorities to pay more attention to issues such as ethical leadership in corporate governance guidelines and to be more sensitive to the approval of the Board of Directors. This study is subject to a number of limitations; consequently, the results should be interpreted with caution. First, the lack of proper cooperation of the $\mathrm{CEO}$ in completing the questionnaire and Second, the existence of other factors affecting the dimensions of the dark personality that cannot be controlled.

\section{Ethical Consideration}

In this article, ethical considerations such as plagiarism, multiple publications, etc., have been considered.

\section{Acknowledgement}

I would like to express my gratitude to all the listed companies' CEO and CFO who helped me to gather some information related to this research.

\section{References}

1. Dechow PM, Dichev ID (2002). The quality of accruals and earnings: The role of accrual estimation errors. Account Rev, 77(1):35-59.

2. Chen $\mathrm{G}$ (2005). The audit opinions of earnings management in listed companies of China. J Mod Account Audit, 1(7): 67-81.

3. Doyle JT, Jennings JN, Soliman MT (2013). Do managers define non-GAAP earnings to meet or beat analyst forecasts? J Account Econ, 56(1): 40-56.

4. Ferrell OC, Fraedrich J, Ferrell L (2008). Business ethics: Ethical decision making. Houghton Mifflin Company, Massachusetts/United States.

5. Etamadi H, Farzani H, Gholami Hosseinabad R, Nazemi Ardakani M (2011). The impact of corporate ethical values on perceptions of earning management. Ethics in Science \& Technology, 5(3, 4): 35-46. (In Persian).

6. Parfet WU. (2000). Accounting subjectivity and earnings management: A preparer perspective. Account Horizons, 14(4): 481-488. 
7. Elias RZ (2004). The impact of corporate ethical values on perceptions of earnings management. Manag Audit J, 19 (1): 84-98

8. DeShong HL, Grant DM, Mullins-Sweatt SN (2015). Comparing models of counterproductive workplace behaviors: the five-factor model and the dark triad. Pers Individ Dif, 74: 55-60.

9. Grijalva E, Harms PD, Newman DA, Gaddis BH, Fraley RC (2015). Narcissism and leadership: A meta-analytic review of linear and nonlinear relationships. Pers Psychol, 68(1): $1-47$.

10. O'boyle EH, Forsyth DR, Banks GC, McDaniel MA (2012). A meta-analysis of the dark triad and work behavior: A social exchange perspective. J Appl Psychol, 97 (3): 557-579.

11. Paulhus DL, Williams KM (2002). The dark triad of personality: narcissism, Machiavellianism and psychopathy. $J$ Res Pers, 36(6): 556-563.

12. Spain SM, Harms P, LeBreton JM (2014). The dark side of personality at work. J Organ Behav, 35(1):41-60.

13. Furtner MR, Rauthmann JF, Sachse P (2011). The selfloving self-leader: an examination of the relationship between self-leadership and the dark triad. Int J Soc Behav Personal, 39(3): 369-379.

14. Jones DN, Paulhus DL (2009). Machiavellianism: handbook of individual differences in social behavior. Guilford Press, New York, NY.

15. Den Hartog DN, De Hoogh AHB (2009). Empowering behavior and leader fairness and integrity: Studying perceptions of ethical leader behavior from a levels-of-analysis perspective. EurJ Work Organ Psychol, 18(2):199-230.

16. Taylor SG, Pattie MW (2014). When does ethical leadership affect workplace incivility? The moderating role of follower personality. Bus Ethics Q, 24(4):595-616.

17. Rauthmann JF (2012). The dark triad and interpersonal perception: Similarities and differences in the social consequences of narcissism, Machiavellianism, and psychopathy. Soc Psychol Personal Sci, 3(4): 487-496.

18. Douglas H, Bore M, Munro D (2012). Distinguishing the dark triad: evidence from the five-factor model and the Hogan development survey. Psychology, 3(03): 237-242.

19. Spector PE, Fox S, Penney LM, Bruursema K, Goh A, Kessler S (2006). The dimensionality of counter productivity: Are all counterproductive behaviors created equal? $J$ Vocat Behaw, 68(3): 446-460.

20. Cohen A. (2016). Are they among us? A conceptual framework of the relationship between the dark triad personality and counterproductive work behaviors (CWBs). Hum Resour Manag Rev, 26(1): 69-85.
21. Palmer JC (2014). Examining ethical leadership as a moderator of the relationship between the dark triad and counterproductive work behavior. Available at: https://opensiuc.lib.siu.edu/theses/1913/

22. Blau G, Andersson L (2005). Testing a measure of instigated workplace incivility. J Occup Organ Psychol, 78(4): 595614.

23. Lata M, Chaudhary R (2020). Dark triad and instigated incivility: the moderating role of workplace spirituality. Pers Individ Dif, 166: 1-11.

24. Brown ME, Treviño LK, Harrison DA (2005). Ethical leadership: A social learning perspective for construct development and testing. Organ Behav Hum Decis Process, 97(2):117-134.

25. Freiwald DR (2013). The effects of ethical leadership and organizational safety culture on safety outcomes. Available at: http://commons.erau.edu/edt/55.

26. Mayer DM, Kuenzi M, Greenbaum RL. (2010). Examining the link between ethical leadership and employee misconduct: the mediating role of ethical climate. J Bus ethics, 95(1):7-16.

27. Lu CS, Lin CC (2014). The effects of ethical leadership and ethical climate on employee ethical behavior in the international port context. J Bus Ethics, 124(2): 209-223.

28. Shiri A, Sharafi SK, Dehghani M, Yasini A (2014). Examining the relationship between managers' narcissism and hypocrisy behaviors with the moderator role of managers' Machiavellian behavior in governmental organizations of Kermanshah city. QJ Public Adm, 3(11): 97-114. (In Persian).

29. Karimi K, Banimahd B, Rahnamay-Roodposhti F (2014). A survey on earnings management and Machiavellianism in Iran. J Appl Emviron Biol Sci, 4(9):157-63. (In Persian).

30. Khajavi S, Dehghani Saadi AA, Gerami Shirazi F (2010). The effect of managers' narcissism on earnings management and financial performance. $J$ Account $A d w, 8(2): 123$ 149. (In Persian).

31. Etamadi H, Rahmani H (2009). No title experimental investigation of ethics in earnings management. Ethics in Science \& Technology, 4(1, 2):79-89. (In Persian).

32. Etamadi H, Dianati Deylami Z (2009). Effects of moral perspective of financial management on the quality of financial reporting of companies. Ethics in Science \& Technology, 4 (1, 2):11-20. (In Persian).

33. Khalifeh Soltani SA, Barzegar G (2016). The relationship between ethical risks and earnings management. J Account knowl, 31(7): 67-90. (In Persian).

34. Moeinaddin M, Nayebzadeh SH, Yavari E (2015). The relationship between ethics and earnings management behavior and the investigation of its effect on demographic 
characteristic. Ethics in Science \& Technology, 10(2):120-32. (In Persian).

35. Hambrick DC, Mason PA (1984). Upper echelons: the organization as a reflection of its top managers. Acad Manag Rev, 9(2):193-206.

36. Shafer WE, Wang Z (2011). Effects of ethical context and Machiavellianism on attitudes toward earnings management in China. Manag Audit J, 26(5): 372-292.

37. Maneiro L, Navas MP, Van Geel M, Cutrín O, Vedder P (2020). Dark triad traits and risky behaviors: identifying risk profiles from a person-centered approach. Int J Environ Res Public Health, 17(17): 6194-6210.

38. Pavlović T, Wertag A (2021). Proviolence as a mediator in the relationship between the dark personality traits and support for extremism. Pers Individ Dif, 168:1-6.

39. D'Souza M, Lima GASF de (2015). The dark side of power: the dark triad in opportunistic decision-making. Adv Sci Appl Accounting, 8(2):135-156.

40. Judge TA, Piccolo RF, Kosalka T (2009). The bright and dark sides of leader traits: A review and theoretical extension of the leader trait paradigm. Leadersh Q, 20(0): 855875.

41. Murphy PR (2012). Attitude, Machiavellianism and the rationalization of misreporting. Accounting, Organ Soc, 37(4): 242-259.

42. Kiazad K, Restubog SLD, Zagenczyk TJ, Kiewitz C, Tang RL (2010). In pursuit of power: the role of authoritarian leadership in the relationship between supervisors' Machiavellianism and subordinates' perceptions of abusive supervisory behavior. J Res Pers, 44(4): 512-519.

43. Kriti J, Bearden JN. (2011). Machiavellianism and overconfidence. Available at: https://ssm.com/ab$\underline{\text { stract }=1774523}$

44. Jonason PK, Slomski S, Partyka J (2012). The dark triad at work: How toxic employees get their way. Pers Individ Dif, 52(3): 449-453.

45. Spurk D, Keller AC, Hirschi A (2016). Do bad guys get ahead or fall behind? Relationships of the dark triad of personality with objective and subjective career success. Soc Psychol Personal Sci, 7(2):113-121.
46. Black PJ, Woodworth M, Porter S (2014). The big bad wolf? the relation between the dark triad and the interpersonal assessment of vulnerability. Pers Individ Dif, 67: 5256.

47. Shafer WE, Simmons RS (2008). Social responsibility, Machiavellianism and tax avoidance. Accounting, Auditing \& Accountability Journal, 21(5): 695-720.

48. Nuzulia S, Why FYP (2020). When the dark shines: the role of dark personality traits in leadership role occupancy and hiring decisions in a collectivistic culture. Soc PsycholPersonal Sci, 8(2):1089-1100.

49. Criag Bulter J (2015). The dark triad, employee creativity, and employee performance in the new venture context. Available at: https://hdl.handle.net/11244/45223.

50. Babiak P, Neumann CS, Hare RD (2010). Corporate psychopathy: talking the walk. Behav Sci L aw, 28(2): 174-193.

51. Smith SF, Lilienfeld SO (2013). Psychopathy in the workplace: the knowns and unknowns. Aggress Violent Behav, 18(2): 204-218.

52. Kasznik R (1999). On the association between voluntary disclosure and earnings management. J Account Res, 37(1): 57-81.

53. Dechow PM, Sloan RG, Sweeney AP (1995). Detecting earnings management. Account Rev, 193-225.

54. Abareshi A (2012). Structural equation modeling. $1^{\text {st }}$ ed. Sociologists Publications, Tehran/ Iran. (In Persian).

55. Dion PA. (2008). Interpreting structural equation modeling results: a reply to Martin and Cullen.J Bus ethics, 83(3): 365-368.

56. Hooper D, Coughlan J, Mullen M (2008). Structural equation modelling: guidelines for determining model fit. Electronic Journal of Business Research Methods, 6(1):53-60 .

57. Steiger JH. (2007). Understanding the limitations of global fit assessment in structural equation modeling. Pers Individ Dif, 42(5):893-898.

58. Kline RB. (2005). Principles and practice of structural equation modeling. $2^{\text {nd }}$ ed. Guilford Press, New York/USA.

59. Scott WR, O'Brien PC (2009). Financial accounting theory. $5^{\text {th }}$ ed. Prentice Hall , Toronto/Canada.

60. Sunani A, Subroto B, Prihatiningtias YW (2010). Do ethical climate and Machiavellianism affect ethical perceptions of earnings management? evidence from Indonesia. Glob J Bus Soc Sci Rev, 2(3): 85-92. 